\title{
OESTROGENIC AND ANTI-OESTROGENIC ACTIVITY OF ANDROGENS IN THE EWE
}

\author{
D. R. LINDSAY AND T. J. ROBINSON \\ Department of Animal Husbandry, University of Sydney, Australia \\ (Received 29th Fune 1962, revised 22nd November 1963)
}

\begin{abstract}
Summary. Seventy-two spayed crossbred ewes were used in a series of five successive tests, at intervals of 15 days, in a study of the actions and interactions of androgen, oestrogen and progesterone on behavioural and vaginal oestrous responses.

Androgen and oestrogen were additive in their action (128 vs. 62 services; $P<0.001)$ on behavioural response, but androgen almost completely inhibited the expected vaginal response to oestrogen.

There was a significant linear decline in behavioural sensitivity from test to test; in the five successive tests, forty-eight, forty-three, thirtyseven, thirty-two and thirty ewes were served $(P<0.001)$. This refractory condition was partly offset by progesterone pretreatment $(P<0.001)$, but oestrogen was necessary to maintain a constant state of psychic reactivity to androgen $(P<0.001)$.

A highly significant linear dose-response relationship was demonstrated with both testosterone and testosterone propionate $(P<0.001)$.
\end{abstract}

\section{INTRODUGTION}

It is well established that libido in women is affected by androgen, presumably of adrenal origin (Salmon \& Giest, 1943) and the presence and production of androgens in ovarian tissue have been demonstrated (Dorfman \& Shipley, 1956; Zander, 1958; Kase, Fochielli \& Dorfman, 1961). On the basis of results obtained when androgen was given prior to PMs-induced ovulation in the anoestrous ewe, Cole (1948) suggested that androgen may be responsible for the induction of oestrous behaviour in the sheep. Subsequently Dauzier \& Wintenberger (1952), Dutt (1952) and Robinson (1952, 1954) found that a period of progesterone pretreatment prior to PMs-induced ovulation commonly resulted in an apparently normal oestrus accompanying this ovulation. Studies with spayed ewes showed that normal oestrus-behavioural and vaginaldepends on an interaction between progesterone and oestrogen. A period of progesterone influence sensitizes the animal to oestrogen (Robinson, 1959).

Lindsay \& Robinson (1961) investigated the action of testosterone in the ewe and found that it had an oestrus-inducing activity comparable to that of oestriol. Behavioural oestrus was not accompanied by vaginal oestrus, and at the doses studied $(1.0$ to $10.0 \mathrm{mg})$ there was no evidence of an interaction between androgen and progesterone pretreatment. 
These studies have been pursued, and the interactions of androgen with progesterone pretreatment and with added oestrogen have been investigated.

\section{MATERIALS AND METHODS}

Seventy-two spayed crossbred ewes were used in a series of five tests conducted at intervals of 15 days. These sheep previously had been standardized to oestradiol benzoate (ODB) for both behavioural and vaginal responses following a standard 12-day period of progesterone priming (Robinson, 1959; Robinson \& Reardon, 1961). The behavioural response was quite precise, with an $\mathbf{E D}_{50}$ of 13 to $16 \mu \mathrm{g}$, while the vaginal response was less so with an ED 50 of 6 to $12 \mu \mathrm{g}$ (95\% fiducial limits).

All seventy-two animals were used in each test and remained in their allotted groups. Each test therefore had a factorial design with the form $2^{3} \times 3(\mathrm{n}=3, \mathrm{~N}=72$; Table 1$)$.

For each test, the standard procedure was to give six injections, each of $20 \mathrm{mg}$ progesterone in $2 \mathrm{ml}$ oil, at intervals of 2 days. Two days after the final injection the test substances (androgen and oestrogen) were administered. All injections were given intramuscularly in oil.

\section{TABLE 1}

PLAN OF EXPERIMENT: SEVENTY-TWO EWES WERE USED FOR FIVE CONSECUTIVE FACTORIAL DESIGN TESTS AT INTERVALS OF 15 DAYS $=360$ OBSERVATIONS

\begin{tabular}{|c|c|}
\hline Comparison & Description \\
\hline $\begin{array}{l}\text { (a) Type of androgen } \\
\text { (b) Pretreatment } \\
\text { (c) Dose of oestrogen } \\
\text { (d) Dose of androgen }\end{array}$ & $\begin{array}{l}\text { Testosterone versus Testosterone propionate } \\
\text { Progesterone versus No progesterone } \\
0 \text { versus } 15.6 \mu \mathrm{g} \\
0.33 \text { versus } 1.00 \text { versus } 3.00 \mathrm{mg}\end{array}$ \\
\hline
\end{tabular}

Design of each test, $n=3 ; N=72$.

Ewes remained in their treatment groups for each test. Data were analysed by a split-plot analysis of variance, with the above four treatments as Main Treatments, and successive tests as Sub-Plots.

Oestrous behaviour and vaginal smear observations were made using standard techniques (see Robinson, 1959). Results were evaluated by a split-plot analysis of variance to single degrees of freedom on the data scored 0 and 1 (rectangular transformation; Biggers, 1951) .

The standard dose of oDB $(15.6 \mu \mathrm{g})$ approximated to the $\mathrm{ED}_{50}$. The doses of androgen were $0.33,1.0$ and $3.0 \mathrm{mg}$ testosterone, with the appropriate adjustment for testosterone propionate to allow for the propionate radicle.

\section{(a) General}

\section{RESULTS}

A total of 190 oestrous responses were observed of the 360 possible cases. Three of the four main treatments incorporated in the experimental design had a significant effect and there was a significant linear decline in the number of responses with successive tests. The main interest lay in the interactions. 
Only twenty-six ewes yielded smears classed as positive, and apart from an apparent effect of dose of androgen, which was not significant, their distribution appeared to be at random.

(b) Main effects-behavioural and vaginal oestrus

Table 2 shows the main effects for both types of response.

For behaviour, there was a significant linear decrease in the number of ewes served in successive tests. Progesterone pretreatment resulted in an almost two-fold increase in the number of ewes served. There was a highly significant

TABle 2

MAIN EFFEGTS

\begin{tabular}{|c|c|c|}
\hline & \multicolumn{2}{|c|}{ No. responses } \\
\hline & Behavioural & Vaginal \\
\hline $\begin{array}{l}\text { Type of androgen } \\
\text { Testosterone } \\
\text { Testosterone propionate } \\
P\end{array}$ & $\begin{array}{r}87 \\
103 \\
\text { N.S. }\end{array}$ & $\begin{array}{r}16 \\
10 \\
\text { N.S. }\end{array}$ \\
\hline $\begin{array}{l}\text { Pretreatment } \\
\text { Progesterone } \\
\text { No progesterone } \\
P\end{array}$ & $\begin{array}{l}121 \\
69 \\
<0 \cdot 001\end{array}$ & $\begin{array}{r}10 \\
16 \\
\text { N.S. }\end{array}$ \\
\hline $\begin{array}{l}\text { Dose of oestrogen } \\
\text { Nil } \\
15.6 \mu g \\
P\end{array}$ & $\begin{array}{l}62 \\
128 \\
<0.001\end{array}$ & $\begin{array}{r}13 \\
13 \\
\text { N.S. }\end{array}$ \\
\hline $\begin{array}{l}\text { Dose of androgen } \\
0.33 \mathrm{mg} \\
1.00 \mathrm{mg} \\
3.00 \mathrm{mg} \\
P \text { (linear) } \\
P \text { (quadratic) }\end{array}$ & $\begin{array}{l}36 \\
68 \\
86 \\
<0 \cdot 001 \\
\text { N.S. }\end{array}$ & $\begin{array}{r}14 \\
6 \\
6 \\
\text { N.S. } \\
\text { N.S. }\end{array}$ \\
\hline $\begin{array}{l}\text { Sub-plots } \\
\text { Test No. } 1 \\
\text { Test No. } 2 \\
\text { Test No. } 3 \\
\text { Test No. } 4 \\
\text { Test No. } 5 \\
P \text { (linear) } \\
P \text { (remainder) }\end{array}$ & $\begin{array}{l}48 \\
43 \\
37 \\
32 \\
30 \\
<0 \cdot 001 \\
\text { N.S. }\end{array}$ & $\begin{array}{r}2 \\
6 \\
6 \\
5 \\
7 \\
\text { N.S. } \\
\text { N.S. }\end{array}$ \\
\hline
\end{tabular}

Significant effects in bold face type.

linear dose-response effect for androgen. Oestradiol benzoate with the androgen had an additive effect at all dose levels of androgen, and resulted in a doubling of the numbers of ewes served.

For vaginal smear, there were no significant effects, but there was a suggestion $(P \fallingdotseq 0 \cdot 10)$ that high doses of androgen-and therefore of behavioural oestrous responses-were associated with a low incidence of positive smears. This is quite contrary to the situation observed in normal or oestrogen-induced oestrus (Robinson \& Moore, 1956). 
(c) Interactions-oestrous behaviour

The significant first and second order interactions are illustrated graphically in Text-figs. 1 to 5.

Text-fig. 1. Test number (linear $) \times$ progesterone pretreatment $(P<0 \cdot 001)$. The overall decline in the numbers of ewes in oestrus (Table 2) was due to a marked

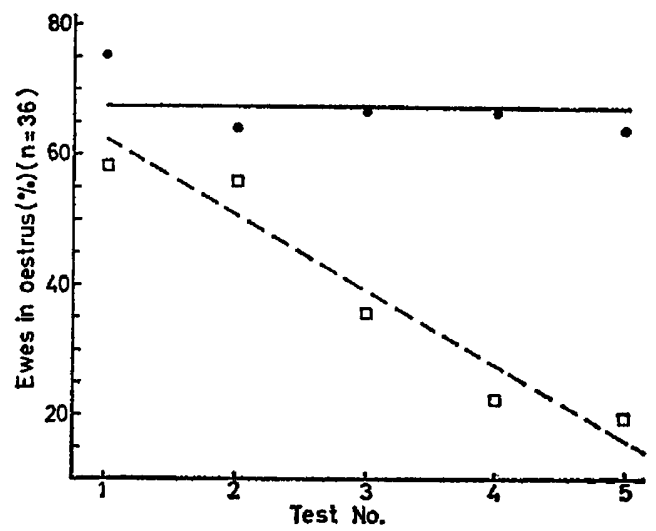

Text-rig. 1. First order interaction-Test number $\times$ progesterone pretreatment $(P<0.001)$. Overall, there was a significant decline from test to test only in the response of ewes not primed with progesterone.

$=$ primed with progesterone.

$\square=$ not primed with progesterone.

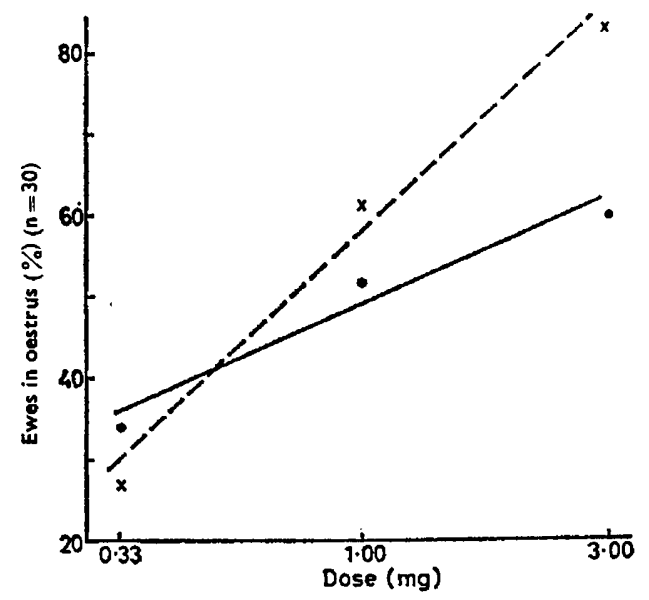

TEXT-FIG. 2. First order interaction-Type of androgen $\times$ dose of androgen $(P<0.05)$.

The dose response line to testosterone propionate $(X)$ is significantly steeper than that to testosterone (O).

drop in sensitivity of the ewes which were not primed with progesterone. Primed ewes retained their overall sensitivity from test to test.

Text-fig. 2. Type of androgen $\times$ dose (linear) $(P<0 \cdot 05)$. The average doseresponse line for testosterone propionate was steeper than that for testosterone.

Testosterone propionate: $y=36 \cdot 5 x+49 \cdot 6$

Testosterone: $\quad y=16 \cdot 2 x+44 \cdot 0$ 
where $\sin ^{2} y=$ proportion of ewes responding

$x=\log _{10}$ dose androgen, expressed as free testosterone.

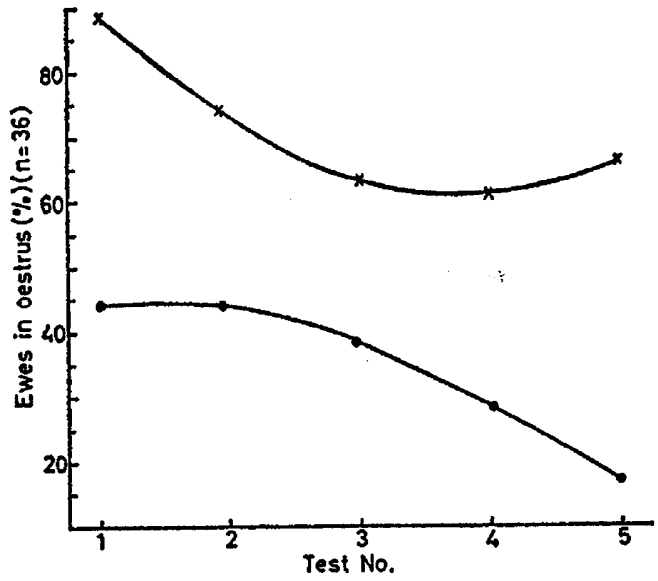

Text-FIG. 3. First order interaction-Test number $\times$ oestrogen $(P<0.01)$. The curves represent the oestrous responses to androgen in successive tests, with $(x)$ or without $(0)$ a supplementary dose of $15.6 \mathrm{\mu g}$ oestradiol benzoate. The inclusion of oestrogen with androgen tends to overcome the overall decline in sensitivity from test to test.

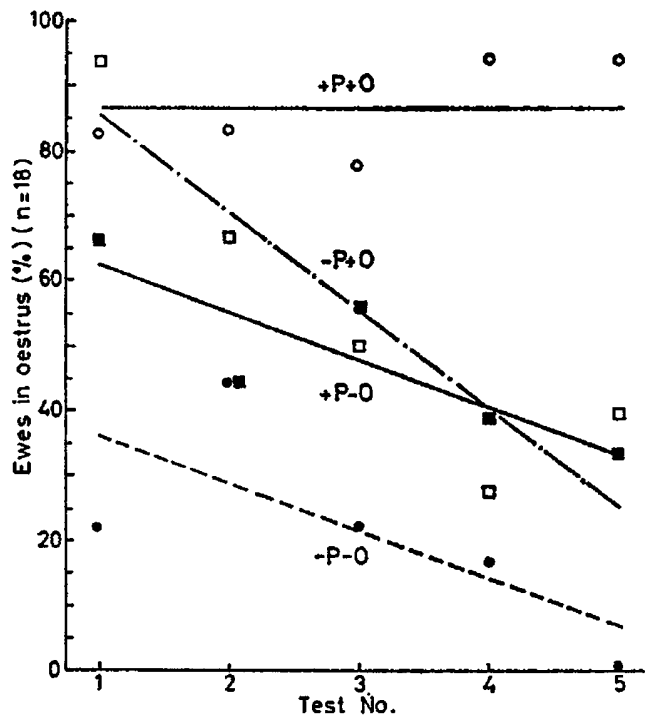

TExT-FIG. 4. Second order interaction-Test number $\times$ oestrogen $\times$ progesterone pretreatment $(P<0.001)$. This figure presents more clearly the principle illustrated in Textfig. 3. A uniform reactivity from test to test requires progesterone priming plus a small supplement of oestrogen with androgen.

Text-fig. 3. Test number (quadratic) $\times$ oestrogen $(P<0 \cdot 01)$. When oestrogen was given with androgen the proportion of ewes responding stabilized after the second test, whereas when androgen was given alone the proportion fell with each test. 
Text-fig. 4. Test number (linear $) \times$ oestrogen $\times$ progesterone pretreatment $(P<0.001)$. This second order interaction is particularly interesting. The response to androgen, given alone, in the first and subsequent tests was increased by progesterone priming. The responses to androgen +oestrogen in the first test were similar for the primed and unprimed ewes, but thereafter the sensitivity of the unprimed animals fell rapidly. The sensitivity fell also, but at a slower rate, for all ewes which received androgen without oestrogen, regardless of whether or not they had been primed with progesterone. The sensitivity of the progesterone-primed ewes which received oestrogen with the androgen remained uniformly high.

Text-fig. 5. Test number (cubic) $\times$ oestrogen $\times$ dose of androgen (linear) $(P<0 \cdot 05)$. This interaction is difficult to interpret but it appears to be, at least in part, a reflection of the greater reliability of response when oestrogen accompanies

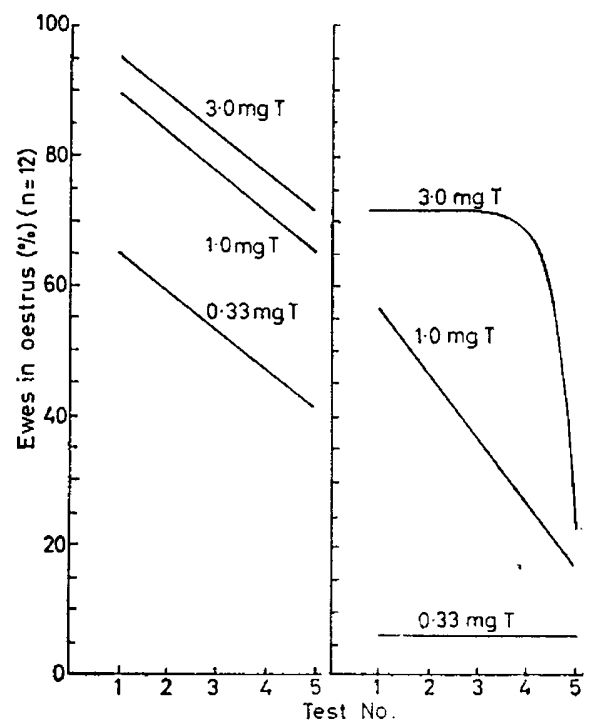

TEXT-FIG. 5. Second order interaction-Test number $\times$ oestrogen $\times$ dose of androgen $(P<0.05)$. This figure shows another aspect of the greater reliability of the response to all doses of androgen when accompanied by a small supplement $(15 \cdot 6 \mu \mathrm{g})$ of oestradiol benzoate. Left: with oestrogen; right: without oestrogen.

the androgen. It is probably partly due, also, to the higher general level of response when oestrogen accompanies testosterone. Thus the total number of responses to $0.33 \mathrm{mg}$ testosterone given alone was so small as to preclude the demonstration of any linear regression of response on test number. The sudden drop in sensitivity, in the fifth test, of animals which received high doses of testosterone without oestrogen, is particularly interesting.

\section{DISGUSSION}

The behavioural response to biologically active steroids is a parameter of hormone action which has been relatively neglected. It is clear that the terms 
'oestrogenic' and 'androgenic', in their commonly accepted context, are largely meaningless when applied to behavioural responses.

There are not enough data from these sheep to attempt to relate behavioural activity to any chemical characteristic of the steroids tested. At least one androgen, testosterone, can produce an apparently normal oestrous response. Further, it appears to interact with progesterone in a manner similar to the oestrogens. This phenomenon was not observed in the preliminary experiments of Lindsay \& Robinson (1961) in which the doses of testosterone were much higher. However, its interaction with progesterone does not seem to be exactly the same as that of oestrogen, for, whereas the sensitivity of the ewe to progesterone with oestrogen remains constant from test to test, that to progesterone with testosterone falls steadily. It is most interesting that this decline in sensitivity can be prevented by the addition of a small supplement of oestrogen with the androgen.

It seems unlikely that these phenomena are due to the conversion of the androgen into compounds with 'oestrogenic' activity, in the generally accepted sense, since there appears to be an antagonistic effect on the vaginal response to administered oestrogen. It seems likely that we are dealing with direct effects upon the central nervous system. There is no suggestion, either, that androgen is normally involved in oestrous behaviour in the sheep. It seems abundantly clear that oestrogen, in association with progesterone, is the hormone involved in cyclic oestrous behaviour (Robinson, 1959). This raises the question of the role of androgen in sexual behaviour of the females of other species, including the human. Does androgen play an important role in 'normal' female behaviour, or is it important only in pathological states such as adrenal virilism? Garm (1949) has made a critical study of nymphomania in cows and has broken this condition down into several categories. Some cases of nymphomania are characterized by cystic ovaries and an apparent over-production of oestrogen. Others are associated with hyperactivity of the adrenal cortex and infantile ovaries, and appear clearly to be examples of adrenal virilism. Behaviour patterns for these extremes appear to be similar, which in view of our experience with oestrogens and androgens in the spayed ewe, is not surprising. But neither Garm's observations nor ours suggest that androgen is involved in the sexual behaviour pattern of the 'normal' cow or ewe.

The main value of work such as that reported here lies in its value as a potential tool for unravelling the complexities of neuro-endocrinological mechanisms involved in behaviour patterns. It is most interesting that the pattern of behavioural response to certain hormones should be dictated by the sex of the recipient. However it must be emphasized that the dose of testosterone needed to elicit a behavioural response is relatively high-some one hundred times as high as that of oestradiol- $17 \beta$-and the fact that the females of several species can react to androgen does not necessarily mean that they normally do. Indeed, the antagonistic action of testosterone, at oestrus-inducing doses, on the characteristic vaginal reaction of the sheep clearly suggests that normally testosterone is not seriously involved in the oestrous behaviour pattern of this species. The same may well be true for other species in which an effect of testosterone on female mating behaviour has been demonstrated. 


\section{ACKNOWLEDGMENTS}

This work forms part of a programme of research into the physiology of reproduction in the sheep financed by the Australian Sheep and Wool Research Committee. One of the authors (D. R. L.) was supported by a Walter and Eliza Hall Agriculture Research Fellowship.

Progesterone was graciously donated by Messrs Fawns and McAllen Pty Ltd, Melbourne, and the androgenic steroids by G. D. Searle and Co, Chicago.

\section{REFERENCES}

BIGGERS, J. D. (1951) The calculation of the dose response line in quantal assays with special reference to oestrogen assays by the Allen-Doisy technique. F. Endocrin. 8, 169.

Cole, H. H. (1948) Hormonal control of estrous behaviour. West. F. Surg. 56, 503.

Dauzier, L. \& Wintenberger, S. (1952) Déclenchement simultané de l'oestrus dans un lot de brebis avec possibilité de gestation ultérieure. Ann. Zootech., Paris, 4, 49.

Dorfman, R. I. \& Shiplex, R. A. (1956) Androgens, biochemistry, physiology and clinical significance. Wiley, New York.

Dutr, R. H. (1952) Induction of estrus and ovulation in anestrual ewes by use of progesterone and pregnant mare serum (Abstract). F. Anim. Sci. 11, 792.

GARM, O. (1949) A study on bovine nymphomania, with special reference to etiology and pathogenesis. Acta endocrin. 2 (Suppl. 3), 1.

Kase, M., Fochizlli, E. \& Dorfman, R. I. (1961) In vitro production of testosterone and androst-4ene-3,17-dione in a human ovarian homogenate. Acta endocrin. 37, 19.

LindsAy, D. R. \& RoBinson, T. J. (1961) The oestrus-inducing activity of testosterone in the ewe. Nature, Lond. 192, 761 .

Rosinson, T. J. (1952) Role of progesterone in the mating behaviour of the ewe. Nature, Lond. 170, 373.

Robrnson, T. J. (1954) The production of coincident oestrus and ovulation in the anoestrous ewe with progesterone and pregnant mare serum. F. Endocrin. 10, 117.

Rorinson, T. J. (1959) Reproduction in domestic animals, vol. 1, chap. 9. Eds. H. H. Cole \& P. T. Cupps. Academic Press, New York.

Robinson, T. J. \& MOORE, N. W. (1956) The interaction of oestrogen and progesterone on the vaginal cycle of the ewe. F. Endocrin. 14, 97.

Robinson, T. J. \& Reardon, T. F. (1961) The activity of a number of oestrogens as tested in the spayed ewe. 7. Endocrin. 23, 97.

Salmon, U. J. \& Giest, S. H. (1943) Effect of androgens upon libido in women. F. clin. Endecrin. 3, 235.

ZANDER, J. J. (1958) Steroids in the human ovary. F. biol. Chem. 232, 117. 